\title{
Glucose-induced Downregulation of Angiotensin II and Arginine Vasopressin Receptors in Cultured Rat Aortic Vascular Smooth Muscle Cells
}

\section{Role of Protein Kinase C}

\author{
Bryan Williams, Phoebe Tsai, and Robert W. Schrier \\ Department of Medicine, University of Colorado School of Medicine, Denver, Colorado 80262
}

\begin{abstract}
Early diabetes mellitus is characterized by impaired responses to pressor hormones and pressor receptor downregulation. The present study examined the effect of elevated extracellular glucose concentrations on angiotensin II (AII) and arginine vasopressin (AVP) receptor kinetics in cultured rat vascular smooth muscle cells (VSMC). Scatchard analysis of $\left[{ }^{3} \mathrm{H}\right]$ AVP and ${ }^{125} \mathrm{I}-\mathrm{AII}$ binding to confluent VSMC showed that high glucose concentrations ( $20 \mathrm{mM}$ ) similarly depressed AVP and AII surface receptor $B_{\max }$ but did not influence receptor $K_{d}$. This receptor downregulation was not reproduced by osmotic control media containing either L-glucose or mannitol. Receptor downregulation was maximal at a glucose concentration of 15-20 $\mathrm{mM}$ and required 24-48 $\mathrm{h}$ for a maximum effect. Normalization of the extracellular glucose concentration allowed complete recovery of AVP and AII binding within $48 \mathrm{~h}$. Receptor downregulation was associated with depressed AVP and AIIstimulated intracellular signaling and cell contraction. High glucose concentrations induced a sustained activation of protein kinase C (PKC) in VSMC, which was prevented by coincubation with H-7. H-7 also markedly attenuated glucose-induced downregulation of AVP and AII receptors on VSMC. This study demonstrates a novel cellular mechanism whereby high extracellular glucose concentrations directly and independently downregulate pressor hormone receptors and their function on vascular tissue via glucose-stimulated PKC activation. (J. Clin. Invest. 1992. 90:1992-1999.) Key words: diabetes mellitus • protein kinase $\mathrm{C} \cdot$ vascular smooth muscle cells • microangiopathy • vascular injury
\end{abstract}

\section{Introduction}

Early diabetes mellitus in both experimental animals and man is associated with increased blood flow to many tissues, including the kidney, myocardium, retina, skin, muscle, and brain (1-7). These early changes in regional hemodynamics have in turn been strongly implicated in the pathogenesis of the widespread microvascular injury that characterizes this disease (810). The principal determinant of this deleterious increase in tissue perfusion is a reduction in arteriolar tone (11). Pressor

Address correspondence and reprint requests to Dr. Robert W. Schrier, C281, University of Colorado School of Medicine, 4200 East 9th Avenue, Denver, CO 80262.

Received for publication 10 January 1992 and in revised form 20 May 1992.

J. Clin. Invest.

(C) The American Society for Clinical Investigation, Inc. 0021-9738/92/11/1992/08 \$2.00

Volume 90, November 1992, 1992-1999 hormones such as angiotensin II (AII $)^{1}$ and arginine vasopressin (AVP) are important modulators of vascular tone (12) and studies of the diabetic rat have demonstrated an early reduction in the aortic contractile response to AII and epinephrine (13). Moreover, glomerular hemodynamic responses to AII are also markedly blunted in diabetic rats (14).

The aforementioned impaired response to pressor hormones could result from either impaired postreceptor actions of the hormone or reduced hormone-receptor binding. In keeping with the latter, reduced glomerular AII binding has been demonstrated in the diabetic rat $(15,16)$; reduced AVP binding to platelet $V_{1}$ receptors has also been observed in patients with diabetes mellitus (17). Additional studies reveal a reduction in the number of beta-adrenergic receptors in experimental diabetes and platelet thromboxane $A_{2}$ receptors in human diabetes $(18,19)$, suggesting that the diabetic state may be associated with a generalized reduction in the expression of a variety of pressor receptors.

In spite of the potential pathophysiological significance of pressor receptor downregulation with regard to the initiation and/or propagation of vascular injury in diabetes, the mechanisms responsible for these marked changes in surface receptor density are unknown. Recent evidence suggests that protein kinase $\mathrm{C}$ (PKC), a multifunctional $\mathrm{Ca}^{2+}$ - and phospholipiddependent serine/threonine kinase system, may play an important role in regulating the cell surface density of many receptors (20-22). In this regard, we have shown that hormoneactivated PKC is an important component of homologous hormone receptor desensitization in cultured rat vascular smooth muscle cells (VSMC) $(23,24)$. Others report a similar PKC-dependent downregulation of a variety of receptors in different tissues (25-27). More recent reports suggest that PKC may modulate surface receptor density by regulating receptor mRNA expression and receptor biosynthesis (28). In view of the potentially important role of PKC in the regulation of receptor biosynthesis and expression, it is intriguing that high extracellular glucose concentrations have recently been shown to promote the activation of PKC in numerous tissues, including vascular tissue, both in vivo and in vitro (29-32). Together, these observations raise the possibility that glucoseinduced PKC activation could provide a novel biochemical mechanism to account for downregulation of pressor receptors in patients with diabetes mellitus.

The present in vitro study thus examines the hypothesis that elevated extracellular glucose concentrations can directly promote the downregulation of AII and AVP receptors on VSMC and thereby impair the subsequent pressor response of VSMC to these hormones via mechanisms dependent on glucose-induced PKC activation in VSMC.

1. Abbreviations used in this paper: AII, angiotensin II; AVP, arginine vasopressin, DAG, diacylglycerol; PKC, protein kinase C; PSS, physiological saline solution; VSMC, vascular smooth muscle cells. 


\section{Methods}

Materials. AVP, AII, and $\mathbf{H} 7$ were purchased from Sigma Chemical Co. (St. Louis, MO). ${ }^{125}$ I-AII and $\left[{ }^{3} \mathrm{H}\right]$ AVP were obtained from New England Nuclear (Wilmington, MA). ${ }^{45} \mathrm{Ca}^{2+}$ was obtained from Amersham Corp. (Arlington Heights, IL). The VRKRTLRRL peptide substrate was a generous gift from Drs. Lynn E. Heasley and Gary L. Johnson, National Jewish Center for Immunology and Respiratory Medicine, Denver, CO.

Preparation of cultured rat VSMC. Rat aortic VSMC were isolated and cultured using a modification of the method described by Chamley et al., as previously described from this laboratory $(23,24,33)$. Briefly, under sterile conditions, aortas were resected from Sprague-Dawley rats and cleaned of adventitia and connective tissue. The vessels were chopped and incubated for $2 \mathrm{~h}$ in Eagle's MEM (Gibco Laboratories, Grand Island, NY) containing $2 \mathrm{mg} / \mathrm{ml}$ collagenase. The resulting cell suspension was plated on 35-mm dishes and grown in MEM containing $2 \mathrm{mM}$ L-glutamine, $2 \mathrm{~g} /$ liter $\mathrm{NaHCO}_{3}, 100 \mathrm{IU} / \mathrm{ml}$ penicillin, 100 $\mathrm{mg} /$ liter streptomycin, and $10 \% \mathrm{FCS}$ at $37^{\circ} \mathrm{C}$ in $95 \%$ humidified air and $5 \% \mathrm{CO}_{2}$. At confluence, VSMC from second through sixth passage were used.

Test media. To examine specifically the effects of various extracellular D-glucose concentrations on AII or AVP binding to VSMC and the subsequent biological and physiological response to these agents, VSMC were exposed to one of four test media: $a$ ) control medium: consisted of MEM supplemented with $10 \%$ FCS and containing $5 \mathrm{mM}$ D-glucose; $b$ ) high glucose medium: identical to the control medium except that it was supplemented with D-glucose to increase the glucose concentration up to $30 \mathrm{mM} ; c$ ) L-glucose osmotic control medium: identical to the control medium but supplemented with a cell permeable but poorly metabolized glucose isomer, L-glucose $(25 \mathrm{mM})$; or $d$ ) mannitol osmotic control medium: identical to the control medium but supplemented with poorly diffusible hexose, mannitol ( $25 \mathrm{mM})$.

Receptor binding studies. The experiments examining AVP and AII binding to VSMC were performed using the radioligands [ ${ }^{3} \mathrm{H}$ ]AVP and ${ }^{125} \mathrm{I}$-AII as previously described (34). To determine AVP binding after preexposure to the test media for various time periods, confluent VSMC monolayers on $35 \times 10$-mm dishes were washed twice with ice-cold binding buffer ( $119.2 \mathrm{mM} \mathrm{NaCl}, 3 \mathrm{mM} \mathrm{KCl}, 1.2 \mathrm{mM} \mathrm{MgSO}_{4}$, $1 \mathrm{mM} \mathrm{CaCl} 2,1.2 \mathrm{mM} \mathrm{KH}_{2} \mathrm{PO}_{4}, 10 \mathrm{mM}$ glucose, $10 \mathrm{mM}$ Hepes, $0.1 \%$ BSA, pH 7.4). The cells were then incubated with the same buffer containing $2 \times 10^{-9} \mathrm{M}\left[{ }^{3} \mathrm{H}\right] \mathrm{AVP}$ (specific activity $67.7 \mu \mathrm{Ci} / \mathrm{mmol}$ ) with or without unlabeled AVP for $90 \mathrm{~min}$ at $4^{\circ} \mathrm{C}$ to prevent receptor internalization and achieve saturation binding conditions. Binding was terminated and the unbound radioligand removed by rapid washing four times with $2 \mathrm{ml}$ ice-cold binding buffer. The cells were then solubilized in $0.1 \%$ SDS and $0.1 \mathrm{~N} \mathrm{NaOH}$ and the cell-associated radioactivity was determined by scintillation counting (Tri-carb 460C; Packard Instrument Co. Inc., Downers Grove, IL). Specific binding of AVP was defined as total binding $\left(2 \times 10^{-9} \mathrm{M}\left[{ }^{3} \mathrm{H}\right] \mathrm{AVP}\right)$ minus nonspecific binding $\left(2 \times 10^{-9} \mathrm{M}\left[{ }^{3} \mathrm{H}\right] \mathrm{AVP}\right.$ and $10^{-6} \mathrm{M}$ unlabeled AVP). A $\left.50-\mu\right]$ aliquot of the solubilized cells was assayed for protein content by the method of Lowry. AII binding studies were performed using similar conditions except that the composition of the binding buffer was 50 $\mathrm{mM}$ Tris- $\mathrm{HCl}, 100 \mathrm{mM} \mathrm{NaCl}$ ( $\mathrm{pH} 7.4$ ), $5 \mathrm{mM} \mathrm{MgCl}_{2}$, supplemented with $0.5 \mathrm{mg} / \mathrm{ml}$ bacitracin and $0.2 \%$ BSA. Specific ${ }^{125}$ I-AII binding to VSMC was defined as total binding ( ${ }^{125} \mathrm{I}$-AII, $50-100 \mathrm{fmol}$, specific activity $10^{5} \mathrm{dpm} / \mathrm{ml}$ ) minus nonspecific binding (unlabeled AII [10 ${ }^{-6}$ $M]$ ). Each binding assay was performed in triplicate and binding constants were determined by Scatchard analysis of binding data fitted to a line.

Measurement of PKC activity in VSMC. For the measurement of in situ PKC activity in VSMC, a modification of the method recently described by Heasley and Johnson $(35,36)$ was used. VSMC were seeded into flat-bottomed 96 -well microtiter plates at a density of $20,000 /$ well. VSMC were maintained in regular growth medium for 1 to $3 \mathrm{~d}$ until confluent. The monolayer was then washed with $200 \mu \mathrm{l}$ of Hanks' balanced salt solution before incubation with one of the four test media described above. After the desired exposure time, the test medium was aspirated and replaced with $40 \mu \mathrm{l}$ of a buffered salt solution containing $137 \mathrm{mM} \mathrm{NaCl}, 5.4 \mathrm{mM} \mathrm{KCl}, 10 \mathrm{mM} \mathrm{MgCl}, 0.3 \mathrm{mM}$ sodium phosphate, $0.4 \mathrm{mM}$ potassium phosphate, $25 \mathrm{mM} \beta$-glycerophosphate, $5.5 \mathrm{mM}$ D-glucose, $5 \mathrm{mM}$ EGTA, $1 \mathrm{mM} \mathrm{CaCl} 2(\sim 100 \mathrm{nM}$ $\mathrm{Ca}^{2+}$-free), $100 \mu \mathrm{M}$ [gamma ${ }^{32} \mathrm{P}$ ] ATP ( $\left.\sim 5,000 \mathrm{cpm} / \mathrm{pmol}\right), 50 \mu \mathrm{g} /$ $\mathrm{ml}$ digitonin, and $20 \mathrm{mM}$ Hepes $\left(\mathrm{pH} 7.2,30^{\circ} \mathrm{C}\right)$. In addition, $100 \mu \mathrm{M}$ of a PKC-specific peptide substrate (VRKRTLRRL) was added to the buffer. This short synthetic peptide is based on the sequence surrounding a major PKC-dependent phosphorylation site within the epidermal growth factor (EGF) receptor (37). This peptide substrate is not phosphorylated by cyclic nucleotide-dependent or $\mathrm{Ca}^{2+} /$ calmodulin-dependent protein kinases or $\mathrm{S} 6$ kinase and has been extensively characterized to be a highly specific substrate for $\operatorname{PKC}(35,36)$. By permeabilizing VSMC with the digitonin contained in the buffer, the VRKRTLRRL peptide enters VSMC along with [gamma ${ }^{32} \mathrm{P}$ ] ATP to allow a highly selective and rapid analysis of in situ PKC activity. The concentration of digitonin $(50 \mu \mathrm{g} / \mathrm{ml})$ used in this assay does not modify VSMC morphology or promote cell detachment. Moreover, PKC activity is retained by the monolayer postpermeabilization (PKC activity in the supernatant was $<10 \%$ total PKC activity). This latter finding is consistent with the concept that the PKC activity being measured using this assay is tightly associated with the cell membrane as has been proposed for the active form of $\operatorname{PKC}(20,38,39)$. The kinase reaction was linear with time for up to $20 \mathrm{~min}$ and was therefore allowed to proceed for $10 \mathrm{~min}$ at $30^{\circ} \mathrm{C}$ before termination by the addition of $25 \%$ (wt/vol) TCA ( final TCA concentration 5\%). Aliquots (45 $\mu \mathrm{l}$ ) of the acidified reaction mixture were spotted onto $2-\mathrm{cm}$ phosphocellulose circles ( P81; Whatman Inc., Clifton, NJ) and washed batchwise: three washes with $75 \mathrm{mM}$ phosphoric acid and one wash with $75 \mathrm{mM}$ sodium phosphate ( $\mathrm{pH} 7.5)(500 \mathrm{ml} / 2-\mathrm{min}$ wash ). Because of the basicity of the VRKRTLRRL substrate, it is retained by the phosphocellulose filter at neutral $\mathrm{pH}$, whereas contaminating [ $\left.{ }^{32} \mathrm{P}\right] \mathrm{ATP}$ is removed. The PKC-dependent phosphorylation of the peptide substrate bound to the filter was quantified by scintillation counting. Results are expressed as PKC-dependent peptide phosphorylation, $\mathrm{pmol} / \mathrm{min}$ per mg VSMC protein.

Measurement of ${ }^{45} \mathrm{Ca}^{2+}$ efflux from VSMC. ${ }^{45} \mathrm{Ca}^{2+}$ efflux studies were performed as previously described $(24,40,41)$. Briefly, after exposure to the test media, confluent VSMC on $35-\mathrm{mm}$ dishes were washed with physiological saline solution (PSS) and incubated with 1 ml fresh test medium containing $8 \mu \mathrm{Ci}^{45} \mathrm{Ca}^{2+}$ (specific activity) for $3 \mathrm{~h}$ at $37^{\circ} \mathrm{C}$ to allow preloading of VSMC with ${ }^{45} \mathrm{Ca}^{2+}$. Thereafter, VSMC were rinsed rapidly $(10 \times 1 \mathrm{ml}$ PSS in $60 \mathrm{~s})$ and then incubated with 1 $\mathrm{ml}$ PSS. The PSS was removed and replaced with fresh PSS at 1-min intervals for $6 \mathrm{~min}$. Samples at each time interval were placed into vials for liquid scintillation counting. After $6 \mathrm{~min}$, the PSS was supplemented with either. AVP $\left(10^{-7} \mathrm{M}\right)$ or AII $\left(10^{-7} \mathrm{M}\right)$ and VSMC were exposed to these agents for $1 \mathrm{~min} .{ }^{45} \mathrm{Ca}^{2+}$ released by VSMC during the incubation with these agents and for subsequent $5 \times 1$-min incubations with $1 \mathrm{ml}$ PSS was quantified by liquid scintillation counting. The VSMC were solubilized as described above and the cell-associated radioactivity was counted. Total ${ }^{45} \mathrm{Ca}^{2+}$ released after the addition of the effector minus basal release was expressed as a percentage of total available cellular radioactivity at the time of stimulation with the effector.

VSMC shape change studies. The functional response of VSMC to AVP or AII was assessed by quantitation of cell surface area changes using phase-contrast microscopy (IM35; Carl Zeiss, Inc., Oberkochen, Germany) and a computerized digital image analyzer (Zidas, Carl Zeiss Inc.) that had been calibrated using a micrometer scale, as previously reported from this laboratory $(23,24)$. For these studies, only sparsely plated primary cultures of VSMC in $35 \times 10$-mm dishes were used because VSMC may lose their contractility after subculture (42). After preexposure to the test media, VSMC were incubated for 20 min in the presence of fresh test media at $37^{\circ} \mathrm{C}$. After this equilibration period, the area of individual cells was measured. A $20 \times$ objective was used for all studies on groups of 10-15 cells. The microscopic field was chosen randomly and not selected for cell shape or size. AVP $\left(10^{-6} \mathrm{M}\right)$ 
or AII $\left(10^{-6} \mathrm{M}\right)$ was then added to the medium and the VSMC incubated for a further $15 \mathrm{~min}$ at $37^{\circ} \mathrm{C}$. Changes in VSMC surface area in the same group of cells in response to AVP or AII was then measured with the image analyzer. Several precautions were incorporated into the protocol. Three measurements of each cell were taken and any group of measurements showing a standard deviation of $>20 \%$ of the mean was discarded. Spontaneous cell shape changes due to manipulation of the culture dishes in the absence of effector was measured at $<5 \%$ and thus only a value of $\geq 15 \%$ change in surface area was considered to be a significant response to AVP or AII. The method has been further validated in this laboratory by comparing the digital image-analyzed assessment of cell surface area changes with the measured area on photographs of the same cells. The results show excellent correspondence between the two methods.

Statistical analysis. Results are expressed as mean \pm SEM. Statistical analysis was made using the paired or unpaired Student's $t$ test or analysis of variance with a Bonferroni correction as appropriate. For each experiment, $n$ refers to the number of studies (each in triplicate).

\section{Results}

Effect of high extracellular glucose concentrations on AVP and AII binding to VSMC. Studies examining AVP and AII binding to VSMC were performed under conditions at which saturation binding occurs for both ligands and at $4^{\circ} \mathrm{C}$ to prevent receptor internalization so that only surface binding was measured. Equilibration binding for both radioligands occurred by $60 \mathrm{~min}$, remained stable over the next $30 \mathrm{~min}$, and was identical in the presence of all test media. The binding characteristics of both radioligands were specific, time and protein dependent, saturable, and stable in VSMC up to sixth passage. For both AVP and AII, the nonspecific binding was always $<15 \%$ and was not affected by exposure to the different test media.

In the presence of the control medium (D-glucose $5 \mathrm{mM}$ ), Scatchard transformation of the binding data for specific $\left[{ }^{3} \mathrm{H}\right] \mathrm{AVP}$ binding to confluent VSMC yielded a linear plot, demonstrating a single class of AVP-binding sites with a maximum number of binding sites $\left(B_{\max }\right)$ of $1.99 \times 10^{-12} \mathrm{~mol} / \mathrm{mg}$ cell protein and a $K_{\mathrm{d}}$ of $2.15 \times 10^{-9} \mathrm{~mol}$ (Fig. 1). In contrast, however, preexposing VSMC for $48 \mathrm{~h}$ to a high glucose medium (D-glucose $20 \mathrm{mM}$ ) markedly reduced AVP binding by almost $40 \%$ versus control medium, due to a significant decline in $B_{\max }\left(1.22 \times 10^{-12} \mathrm{~mol} / \mathrm{mg}\right.$ cell protein $)$ with no significant change in $K_{\mathrm{d}}\left(2.26 \times 10^{-9} \mathrm{~mol}\right)$ (Fig. 1$)$.
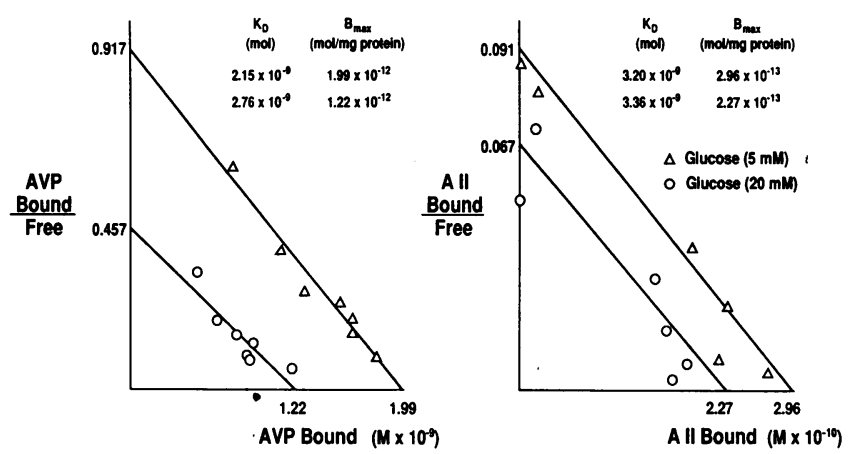

Figure 1. A representative Scatchard analysis comparing the effects of a 48-h exposure to either a normal extracellular glucose concentration ( $5 \mathrm{mM}$ ) (open triangles) or a high extracellular glucose concentration $(20 \mathrm{mM})$ (open circles) on [ $\left.{ }^{3} \mathrm{H}\right] \mathrm{AVP}$ - and ${ }^{125} \mathrm{I}$-AII-specific surface binding to confluent rat VSMC. Similar results were obtained in two additional studies for each peptide.
Similarly, in the presence of control medium, AII binds to a single class of receptors on VSMC with a $B_{\max }$ of $2.96 \times 10^{-13}$ $\mathrm{mol} / \mathrm{mg}$ cell protein and a $K_{\mathrm{d}}$ of $3.2 \times 10^{-9} \mathrm{~mol}$ (Fig. 1). However, preexposure of VSMC to a high glucose medium (D-glucose $20 \mathrm{mM}$ ) for $48 \mathrm{~h}$ resulted in a marked reduction in AII binding to VSMC. This was similar in magnitude to the effect of the high glucose environment on AVP binding to VSMC and was also due to a significant reduction in AII receptor $B_{\max }\left(2.27 \times 10^{-13} \mathrm{~mol} / \mathrm{mg}\right.$ cell protein $)$ with no significant change in $K_{d}\left(3.36 \times 10^{-9} \mathrm{~mol}\right)$. Thus exposing VSMC to a high extracellular glucose environment resulted in a significant decrease in AVP and AII binding to VSMC in both cases due to a similar decline in surface density of these pressor receptors with no significant change in receptor affinity. These changes did not reflect changes in VSMC protein content or cell number as both of these parameters were equivalent after a 48-h exposure of confluent VSMC to all test media. Furthermore, the glucose-induced decrease in hormone binding did not represent VSMC toxicity or accelerated cell death because cell detachment rates, percent lactate dehydrogenase release and percent trypan blue exclusion, were also similar after a 48-h exposure to all test media (data not shown).

To examine the possibility that changes in AVP or AII surface binding were related to the increased extracellular osmolality of the high glucose medium, the effects of a 48-h exposure to the two osmotic control media (L-glucose or mannitol) on AVP and AII binding to VSMC was examined. The results indicate that the downregulation of AVP and AII receptors on VSMC was specific for D-glucose and is not reproduced by either of the two osmotic test media (Table I). Moreover, the fact that high concentrations of the poorly metabolized L-glucose isomer did not modify AVP or AII binding to VSMC suggests that intracellular metabolism of D-glucose is necessary for its effects on pressor receptor expression to develop.

Glucose concentration dependency of $A V P$ and $A I I$ receptor downregulation in VSMC. The next study examined the relationship between extracellular glucose concentration and depression of AVP and AII binding to VSMC. Confluent VSMC were incubated with different D-glucose concentrations for 48 $h$ before determining the binding of $\left[{ }^{3} \mathrm{H}\right] A$ VP or ${ }^{125} \mathrm{I}-\mathrm{AII}$ to VSMC. The glucose concentration dependency of inhibition of AVP and AII binding to VSMC was a threshold effect with the specific binding of both hormones being significantly depressed at a glucose concentration of $15 \mathrm{mM}$ and maximally depressed between 15 and $20 \mathrm{mM}$ (Fig. 2).

Table I. Effect of a 40-h Incubation with the Different Test Media on the Specific Binding of $\left[{ }^{3} H\right] A V P$ and ${ }^{125} I-A I I$ to Confluent VSMC

\begin{tabular}{ccc}
\hline \multicolumn{1}{c}{ Test media } & AVP & AII \\
\hline \multicolumn{3}{c}{ \% specific binding } \\
Glucose $(5 \mathrm{mM})$ & 100 & 100 \\
L-glucose control & $103.9 \pm 5.4$ & $101.0 \pm 6.1$ \\
Mannitol control & $98.7 \pm 5.2$ & $100.8 \pm 7.3$ \\
Glucose $(20 \mathrm{mM})$ & $61.8 \pm 4.9^{*}$ & $66.3 \pm 5.5^{*}$
\end{tabular}

Specific binding in the presence of control medium (glucose $5 \mathrm{mM}$ ) is designated $100 \%$ and results in the presence of the other test media are expressed as percentage of this control. ${ }^{*} P<.01$ vs control. 


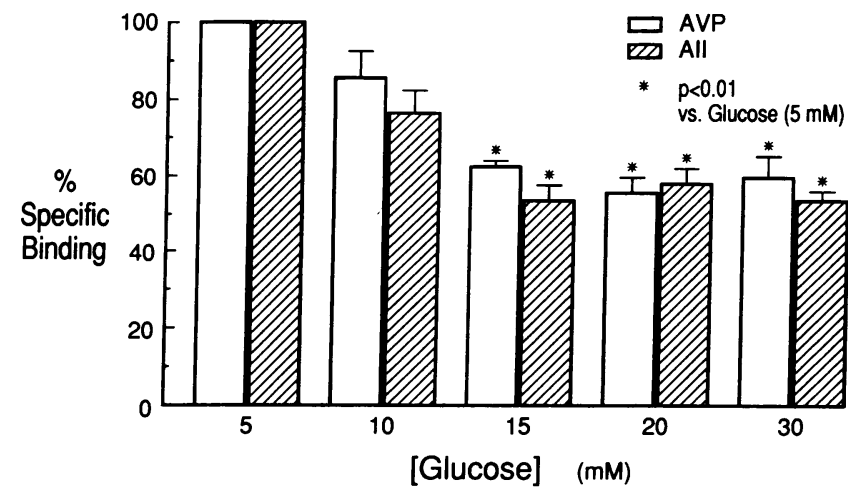

Figure 2. The glucose concentration dependency of AVP- and AII-specific surface binding to confluent VSMC. VSMC were exposed to either control medium (glucose $5 \mathrm{mM}$ ) or identical medium supplemented with various concentrations of D-glucose for $48 \mathrm{~h}$ before determining the specific surface binding of AVP (open bars) and AII (hatched bars). AVP or AII binding in presence of control medium is designated $100 \%$ and binding in the presence of the other test media is expressed as percent of control. ${ }^{*} P<0.01$ vs. control binding ( $n$ $=3$ ).

Time dependency of glucose-induced downregulation of $A V P$ and AII receptors on VSMC. To examine the time dependency of the downregulation of AVP and AII receptors in the presence of a high glucose concentration, VSMC were exposed to a glucose concentration of $20 \mathrm{mM}$ for increasing time periods up to $48 \mathrm{~h}$. Fig. 3 shows that $>12$-h exposure to a high D-glucose concentration was required to significantly downregulate either the AVP or AII receptor and between 24 and $48 \mathrm{~h}$ was required for maximal glucose-induced downregulation of these receptors on VSMC. The maximum time exposure to the high glucose medium in all studies was $48 \mathrm{~h}$.

Recovery of AVP and AII receptors. Having demonstrated the slow onset of glucose-induced pressor receptor downregulation, the next study examined receptor recovery after restoring the extracellular glucose concentration to normal. VSMC were exposed to a high D-glucose concentration ( $20 \mathrm{mM}$ ) for $48 \mathrm{~h}$ to

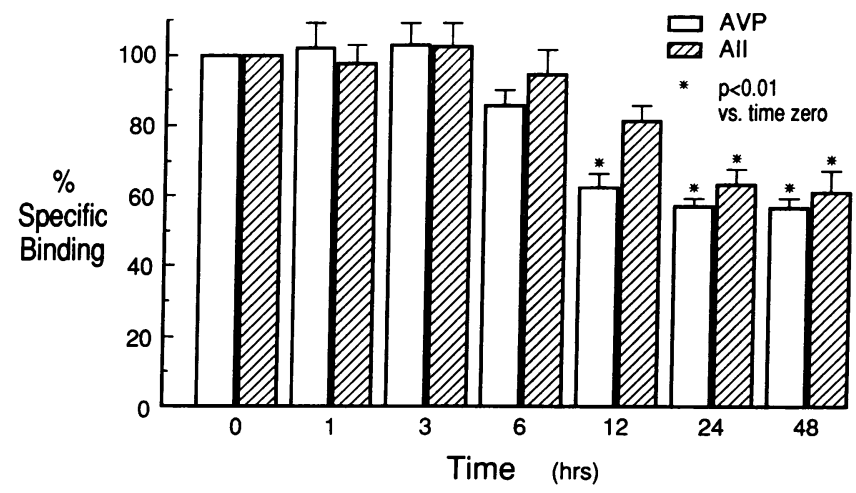

Figure 3. The time dependency of glucose-induced inhibition of AVP and AII binding to VSMC. Confluent VSMC were exposed to a control medium (glucose $5 \mathrm{mM}$, time 0 ) or a high extracellular glucose medium (glucose $20 \mathrm{mM}$ ) concentration for various time periods. Control AVP- (open bars) and AII- (hatched bars) specific surface binding (time 0 ) was designated $100 \%$ and peptide hormone binding after varying exposure to the high glucose medium is expressed as percent control. ${ }^{*} P<0.01(n=3)$. induce maximal downregulation of AVP and AII receptors. The high glucose medium was then replaced with control medium (glucose $5 \mathrm{mM}$ ) for various time periods before measuring specific AVP or AII binding to VSMC. The characteristics of AVP and AII receptor recovery were very similar. Both receptors showed signs of recovery within $12 \mathrm{~h}$ of normalizing the extracellular glucose concentration but required up to $48 \mathrm{~h}$ for full receptor recovery to occur (Fig. 4). These results demonstrate that glucose-induced effects on both AVP and AII surface receptors on VSMC are similarly slow to develop and slow to recover. Furthermore, the complete reversibility of this phenomenon confirms that glucose-induced receptor downregulation does not involve any artifact due to cell death.

Glucose-induced activation of PKC in VSMC. The next series of studies were designed to explore whether PKC activation is involved in the mechanism(s) whereby glucose promoted the downregulation of pressor receptors on VSMC. PKC activation has been implicated in the regulation of hormone receptor biosynthesis and expression. Elevated extracellular glucose concentrations have been shown to induce the activation of PKC in cultured retinal endothelial cells and isolated glomeruli via an increased flux of glucose through an intracellular pathway culminating in the enhanced de novo synthesis diacylglycerol (DAG) $(29,32)$, which in turn promotes the activation of PKC $(20,38)$. The next series of studies thus examined whether elevated glucose concentrations activate PKC in VSMC. Fig. 5 shows that after a 3-h exposure to a high D-glucose (20 mM) medium, in situ PKC activity was markedly increased compared with the PKC activity measured in VSMC exposed to control medium (glucose, $5 \mathrm{mM}$ ). Of interest, the glucose-induced increase in PKC activity was sustained for up to $48 \mathrm{~h}$, provided that the extracellular glucose concentration remained elevated. In contrast, 48-h exposure to either of the two osmotic control media produced no appreciable activation of PKC, confirming that PKC activation was not osmotically mediated but required the metabolism of glucose (data not shown). Further studies confirmed that PKC activation was glucose-concentration dependent. A threshold glucose concentration of 15 to $20 \mathrm{mM}$ was required to induce a maximal PKC response to glucose (data not shown).

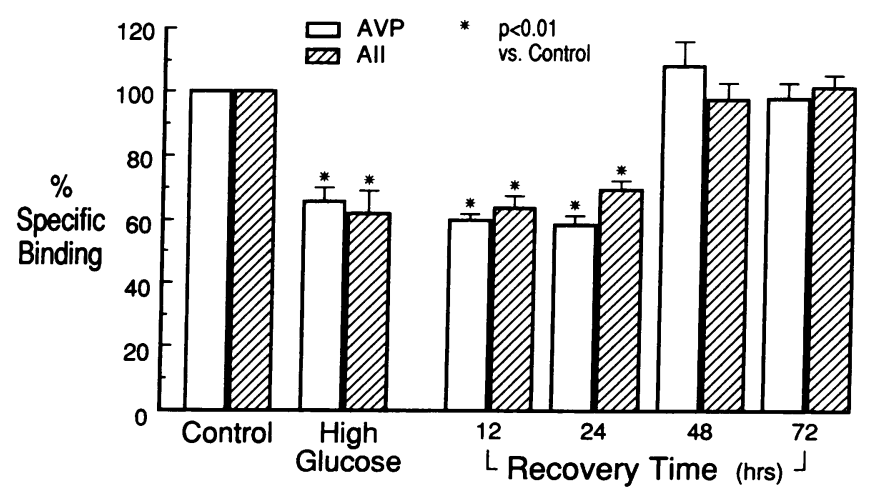

Figure 4. Recovery of AVP and AII surface binding to VSMC after normalization of extracellular glucose concentrations. Confluent VSMC were exposed to control medium or high glucose medium (20 $\mathrm{mM}$ ) for $48 \mathrm{~h}$ to induce AVP and AII receptor downregulation. The culture medium overlying the cells was then replaced with control medium (glucose $5 \mathrm{mM}$ ) for varying time periods before determining the recovery of AVP (open bars) and AII (hatched bars) surface receptor binding. ${ }^{*} P<0.01$ vs. control binding (glucose $\left.5 \mathrm{mM}\right)(n=3)$. 


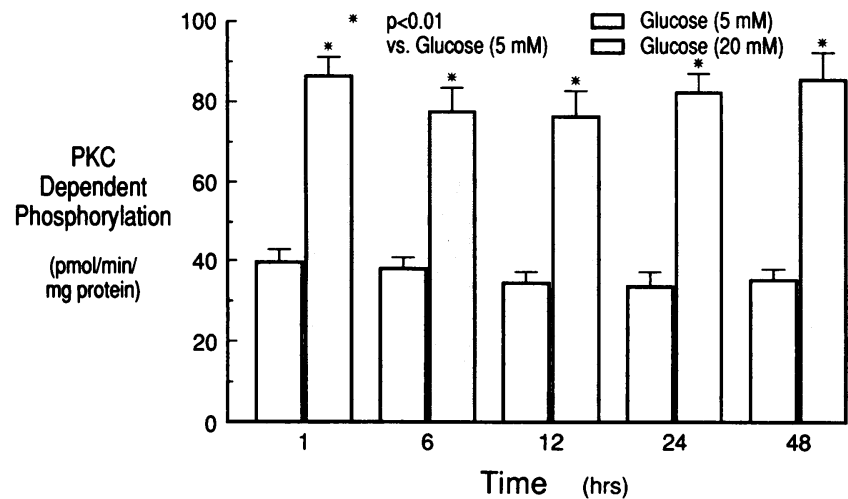

Figure 5. Glucose-induced PKC activity in VSMC. Confluent VSMC were exposed for varying time periods to control medium (glucose $5 \mathrm{mM}$ ) (open bars) or high glucose medium (glucose $20 \mathrm{mM}$ ) (spotted bars) before measuring PKC activity. PKC activity was measured in situ in digitonin-permeabilized VSMC by determining the phosphorylation of the PKC-specific VRKRTLRRL peptide substrate. Results are expressed as pmol phosphate transfered to this substrate/ min per mg VSMC protein. ${ }^{*} P<0.01$ vs. the time-matched control $(n=4)$.

To examine the role of glucose-induced PKC activation in mediating pressor receptor downregulation, a means of manipulating PKC activation by glucose was necessary. The next study determined the capacity of $\mathrm{H} 7$, a relatively specific inhibitor of PKC activity (43), to prevent glucose-induced PKC activation. VSMC were coincubated with $\mathrm{H} 7\left(5 \times 10^{-5} \mathrm{M}\right.$ in $0.1 \%$ DMSO) in either control medium or high glucose (20 mM) medium for $48 \mathrm{~h}$ before determining in situ PKC activity. DMSO $(0.1 \%)$ alone had no effect on basal or glucose stimulated PKC activity (data not shown). With control medium, H7 reduced basal PKC activity. Moreover, when high glucose medium was coincubated with $\mathrm{H} 7$, glucose-induced PKC activation was almost completely prevented (Fig. 6). The fact that the phosphorylation of the VRKRTLRRL peptide substrate was markedly attenuated by a recognized PKC inhibitor $(\mathrm{H} 7)$ demonstrates that the phosphorylating activity being measured in the permeabilized VSMC was specific for PKC.

The role of $P K C$ in glucose-induced $A V P$ and AII receptor downregulation in VSMC. After demonstrating that the sustained activation of PKC induced by chronic high glucose exposure could be prevented by coincubation with $\mathrm{H} 7$, the same

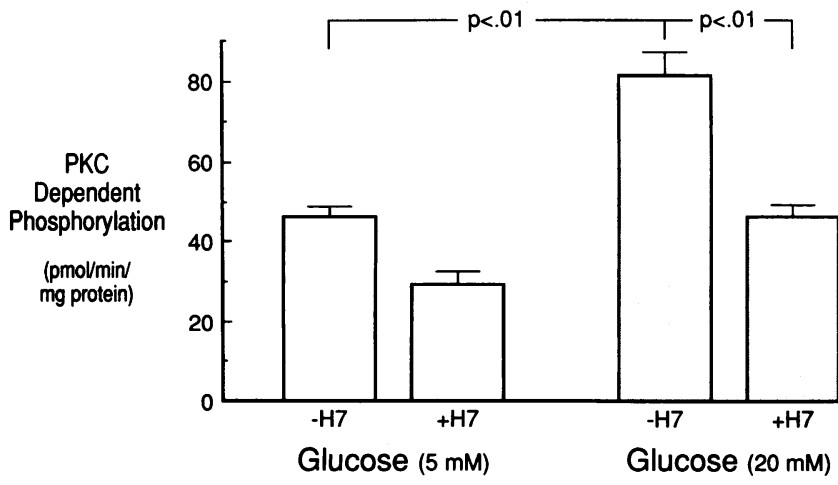

Figure 6. Inhibition of glucose-induced PKC activation by H7. Confluent VSMC were exposed to either control medium (glucose $5 \mathrm{mM}$ ) (open bars) or high glucose medium (glucose $20 \mathrm{mM}$ ) (spotted bars) $\pm \mathrm{H} 7\left(5 \times 10^{-5} \mathrm{M}\right)$ for $48 \mathrm{~h}$ before measuring in situ PKC activity ( $n$ $=3)$. experimental maneuver was used to examine specifically the role of PKC in mediating glucose-induced pressor receptor downregulation in VSMC. Fig. 7 shows that, in the absence of $\mathrm{H} 7,48-\mathrm{h}$ exposure to high glucose $(20 \mathrm{mM})$ medium resulted in a significant downregulation of AVP and AII receptors on VSMC. In contrast, when the high glucose medium was supplemented with $\mathbf{H} 7$ to prevent glucose-induced PKC activation, the downregulation of AVP and AII receptors was almost completely prevented. These results illustrate that glucose-induced downregulation of AVP and AII receptors is strongly dependent on the capacity of glucose to activate PKC in VSMC. Moreover, it is of interest that inhibition of basal PKC activity, in the presence of control medium, increased the expression of both AVP and AII receptors, suggesting that PKC activity is involved in regulating the basal expression of these receptors.

Functional significance of glucose-induced pressor receptor downregulation in VSMC. Spare pressor receptors exist on many tissues in vivo. Thus, the next series of studies examined whether glucose-induced depression of AVP and AII receptor number was biochemically and functionally significant in VSMC. After binding to their specific receptors, both AVP and AII elicit similar intracellular signaling responses in VSMC, which culminate in the mobilization of $\mathrm{Ca}^{2+}$ from intracellular stores $(34,44)$. This release of intracellular $\mathrm{Ca}^{2+}$ is associated with an increased rate of extrusion of $\mathrm{Ca}^{2+}$ from the cell. The measurement of this $\mathrm{Ca}^{2+}$ efflux is, therefore, a measure of the magnitude of the intracellular signaling response to AVP or AII (34). Fig. 8 shows that AVP $\left(10^{-7} \mathrm{M}\right)$ or AII $\left(10^{-7} \mathrm{M}\right)$ are efficacious in stimulating $\mathrm{Ca}^{2+}$ efflux from VSMC. Similar results were obtained using confluent VSMC that had been preexposed to the osmotic control media (Fig. 8). In contrast, after a 48 -h preexposure to a high glucose $(20 \mathrm{mM})$ medium, there was a marked ( $\sim 30 \%$ of control) and significant reduction in the amount of $\mathrm{Ca}^{2+}$ effluxed from confluent VSMC in response to AVP or AII. The percent of total ${ }^{45} \mathrm{Ca}^{2+}$ effluxed from VSMC over a 5-min period under basal, unstimulated conditions was similar after up to $48 \mathrm{~h}$ preexposure to each of the test media. Thus, the $30 \%$ versus control depression of AVP- or AII-stimulated ${ }^{45} \mathrm{Ca}^{2+}$ efflux after preexposing VSMC to a high glucose medium reflects primarily a decrease in the intracellular signaling response to those pressor hor-

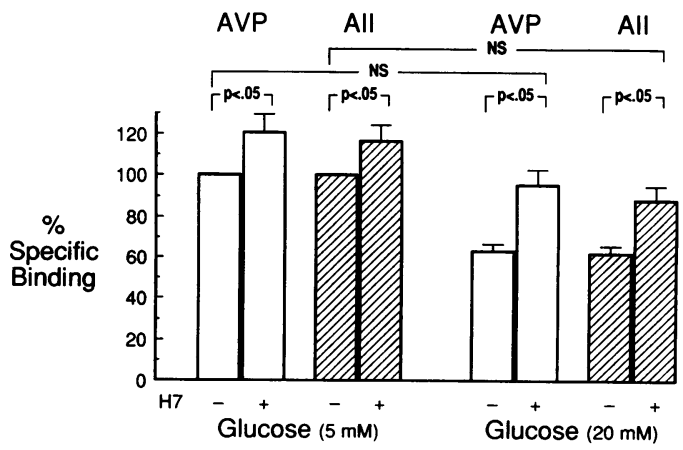

Figure 7. Effect of PKC inhibition on glucose-induced AVP and AII receptor downregulation in VSMC. Confluent VSMC were exposed to either control medium (glucose $5 \mathrm{mM}$ ) or high glucose medium (glucose $20 \mathrm{mM}) \pm \mathrm{H} 7\left(5 \times 10^{-5} \mathrm{M}\right)$ for $48 \mathrm{~h}$ before determining the surface binding of AVP and AII to VSMC. Specific AVP (open bars) and AII (hatched bars) binding in the presence of control medium $(-\mathrm{H} 7)$ was designated $100 \%$ and binding in the other experimental groups is expressed as percent of control $(n=3)$. 


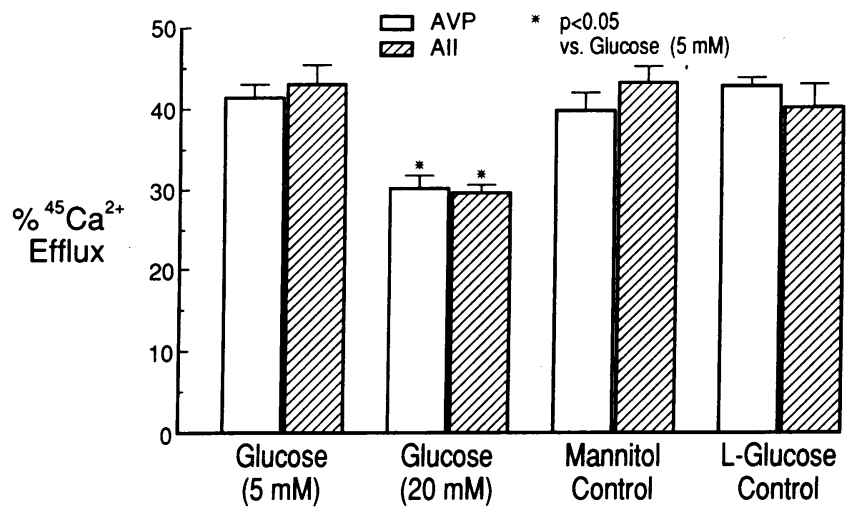

Figure 8. Effect of a high extracellular glucose concentration on AVP and AII induced ${ }^{45} \mathrm{Ca}^{2+}$ efflux from VSMC. Confluent VSMC were incubated with either control medium (glucose $5 \mathrm{mM}$ ) or high glucose medium (glucose $20 \mathrm{mM}$ ) for $48 \mathrm{~h}$ and then preloaded with ${ }^{45} \mathrm{Ca}^{2+}$. AVP- $\left(10^{-7}\right)$ (open bars) and AII- $\left(10^{-7} \mathrm{M}\right)$ (hatched bars) stimulated ${ }^{45} \mathrm{Ca}^{2+}$ efflux from VSMC was measured over a 5 -min period and was expressed as percent total cell ${ }^{45} \mathrm{Ca}^{2+}$ available at the time of stimulation. ${ }^{*} P<0.05$ vs. all of the control media $(n=4)$.

mones rather than any change in the basal efflux rate. Furthermore, these data suggest that the magnitude of AVP and AII receptor downregulation is paralleled by a proportionate decrease in intracellular signaling.

The process of $\mathrm{Ca}^{2+}$ mobilization in VSMC is closely linked to the intracellular mechanisms regulating cell contraction (44, 45 ). The next study therefore examined whether the glucoseinduced downregulation of AVP and AII receptors on VSMC was also associated with impaired VSMC contractile responses to AVP and AII. Sparsely plated individual primary cultures of VSMC were incubated with one of the four test media for $48 \mathrm{~h}$ before examining VSMC contraction in response to AVP or AII $\left(10^{-6} \mathrm{M}\right)$. Contraction was defined as a $>15 \%$ reduction in surface area, measured using microscopic digital planimetry. Spontaneous contraction of cells due to manipulation of the media was the same after preexposure to all test media. Moreover, median cell planar surface area was not significantly different after exposure to different test media, thus contractile responses were measured from a similar baseline surface area in the presence of all test media. In the presence of control medium, almost $50 \%$ of VSMC underwent a significant contractile response after a 15-min exposure to either AVP or AII, compatible with data previously published from this laboratory $(23,24,44)$. Results in the presence of the mannitol or L-glucose media were equivalent to control. However, after a 48-h exposure to a high D-glucose ( $20 \mathrm{mM})$ medium, the contractile response of VSMC to AVP and AII was significantly impaired (Fig. 9). These data complement the signal-transduction studies in suggesting that the PKC-dependent downregulation of AVP and AII receptors on VSMC exposed to a high glucose environment is associated with a significant depression of biochemical and physiological responses of VSMC to these pressor hormones.

\section{Discussion}

Several in vivo studies demonstrate that the early diabetic state is associated with a downregulation of diverse classes of pressor receptor on a variety of tissues (15-19). In spite of its potential

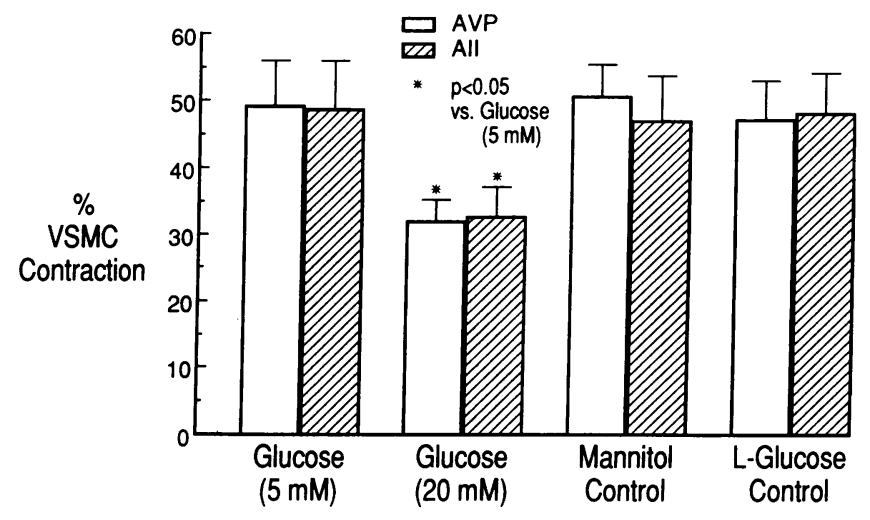

Figure 9. Effect of a high extracellular glucose concentration on the VSMC contractile response to AVP and AII. Sparsely plated primary cultures of VSMC were incubated with either control medium (glucose $5 \mathrm{mM}$ ) or high glucose medium (glucose $20 \mathrm{mM}$ ) for $48 \mathrm{~h}$ before measuring the contractile response of individual VSMC using microscopic digital planimetry after a 10 -min exposure to AVP $\left(10^{-6} \mathrm{M}\right)$ (open bars) or AII $\left(10^{-6} \mathrm{M}\right)$ (hatched bars). ${ }^{*} P<0.05$ vs. all of the control media. Each column represents the mean of measurements made on a total of $\sim 100$ individual cells in four separate experiments.

pathophysiological significance with regard to vascular injury in diabetes mellitus, the factors responsible for receptor downregulation remain undefined. Hyperglycemia is the characteristic metabolic abnormality of diabetes mellitus and some studies demonstrate that an inverse relationship may exist between blood glucose concentration and hormone receptor density $(16,19)$. Treating rats with insulin to maintain euglycemia prevents glomerular AII receptor downregulation (16). Furthermore, in diabetic patients, there is a significant negative correlation between platelet thromboxane $\mathrm{A}_{2}$ receptor number and glycosylated hemoglobin $A 1_{c}$ levels (19), the latter being a measure of recent glycemic control. However, because of the multiplicity of factors that can influence the regulation of receptor expression, it has been impossible to examine the specific and independent effect of an elevated extracellular glucose concentration in vivo. To this purpose, the present study used an in vitro cell culture system to exclude other variables and uniquely demonstrates a direct and specific effect of high extracellular glucose concentrations to downregulate AVP and AII receptors on vascular tissue. This effect is not attributable to changes in extracellular osmolality but is dependent on the metabolism of D-glucose. The receptor downregulation was apparent using glucose concentrations compatible with those attained in poorly controlled diabetic patients.

Analysis of receptor-binding kinetics reveals a similar effect of high extracellular glucose concentrations on both AVP and AII binding to VSMC. The specific binding of both pressor hormones to VSMC was depressed due to a significant reduction in surface density of each receptor type rather than any significant change in receptor affinity. Of interest, similar characteristics for pressor receptor downregulation have been observed early in the course of experimental and human diabetes mellitus. In the rat glomerulus, AII receptors are downregulated within $24 \mathrm{~h}$ of onset of diabetes mellitus $(15,16)$ and, in diabetic patients, the AVP $\left(V_{1}\right)$ and the thromboxane $A_{2}$ receptor are downregulated on the surface of platelets $(17,19)$. In each instance, the diminished hormone binding resulted from decreased receptor density without a significant change in re- 
ceptor affinity, an identical response in vitro to the effect of glucose on pressor receptors demonstrated in the present study. In addition, the magnitude of receptor downregulation due to diabetes mellitus in vivo (30-58\%) is similar to the maximal glucose-induced response of $\sim 40 \%$. In each in vivo study, decreased pressor receptor number in diabetic animals and man could not be explained by previous receptor occupancy or homologous desensitization due to reciprocal changes in circulating levels of the relevant hormone $(15-17,19)$. Moreover, more detailed studies of the AII receptor revealed appropriate AII receptor regulation in diabetic rat glomeruli after pharmacological manipulation of the renin-angiotensin system (15, 16). These latter observations imply a direct effect of a metabolic consequence of the diabetic state on pressor receptor expression. One major consequence is hyperglycemia and the present in vitro study illustrates that a potent and specific effect increased glucose to downregulate AVP and AII receptors on cultured VSMC. This effect is both qualitatively and quantitatively similar to the effects of the diabetic state on these receptors in vivo. Although it is impossible to extrapolate directly from in vitro data to the in vivo situation, this striking correspondence does suggest that the previously documented effects of diabetes on pressor receptor kinetics in vivo may be a direct consequence of an elevated extracellular glucose concentration. The present results also provide information about the cellular mechanism whereby this effect of glucose may be mediated.

PKC may be important in regulating the expression of a diverse population of cell surface receptors in a variety of tissues (25-28). The present study demonstrates that high extracellular glucose concentrations induce a sustained increase in the activity of PKC in VSMC. This observation is compatible with those of others, which show a glucose-dependent activation of PKC in many tissues in vivo and in vitro (29-32). Using isolated glomeruli, Craven and coworkers recently demonstrated that elevated glucose concentrations increase the flux of glucose through an intracellular pathway that culminates in the enhanced de novo synthesis of DAG and concluded that this increase in DAG mass may contribute to glucose-induced activation of PKC $(29,32)$. Numerous studies in diabetic animals confirm that DAG levels are indeed elevated in a variety of tissues, including vascular tissue $(29,31,32,46)$. The present study lends support to the aforementioned hypothesis of Craven and coworkers by demonstrating that elevated extracellular glucose concentrations of the nonmetabolized glucose isomer, L-glucose, do not activate PKC, implying that a product of glucose metabolism, perhaps DAG, is required for glucose-induced activation of PKC in VSMC.

To explore the relevance of the sustained activation of PKC by glucose to the process of glucose-induced receptor downregulation in vascular tissue, glucose-induced PKC activation was prevented with $\mathrm{H} 7$, a relatively specific inhibitor of PKC activation (43). This maneuver almost completely prevented glucose-induced downregulation of the AVP or AII receptor, providing strong evidence that glucose-induced pressor receptor downregulation is dependent on the capacity for glucose to activate PKC in VSMC. It is important to note, however, that $\mathrm{H} 7$ is not totally specific for PKC and it therefore remains possible that the concomitant inhibition of other kinase systems could be contributing to the effects of $\mathrm{H} 7$ on glucose-induced receptor downregulation, as observed in the present study.
The present study demonstrates a slow onset and slow recovery of glucose-induced AVP and AII receptor downregulation, requiring hours. The recycling time for the AVP $\left(V_{1}\right)$ and AII receptors, however, is rapid in VSMC, 15-20 min (47, 48). An effect of glucose to inhibit this process would have been more immediately apparent. Thus the slow downregulation of AVP and AII receptors by the high glucose environment and their slow recovery is more likely to reflect modulation of receptor biosynthesis. An effect of PKC on epidermal growth factor receptors has suggested this mechanism in the Swiss/ 3T3 line. It thus seems possible that the PKC dependency of the observed glucose-mediated receptor downregulation may inhibit the expression of receptor mRNA.

Diabetes-induced downregulation of pressor receptors may be relevant to the increased blood flow to many tissues that has been implicated as an important factor in the early pathogenesis of microvascular injury (8-10). The present study thus explored the biochemical and functional significance of glucoseinduced AVP and AII receptor downregulation in VSMC. The results show that AVP- and AII-stimulated $\mathrm{Ca}^{2+}$ efflux from VSMC and the contractile response of individual VSMC to these agents are markedly attenuated after preexposing VSMC to a high glucose environment for $48 \mathrm{~h}$. As in the effects on receptor density and PKC activation, these effects were specific for the high D-glucose medium. Moreover, the magnitude of glucose-induced AVP or AII receptor downregulation appeared to parallel the glucose-induced defect in AVP- and AIIstimulated intracellular signaling and contractility in VSMC. Although this does not prove causality, recent studies have demonstrated that there are few, if any, spare $\mathrm{V}_{1}$ or AII receptors on $\operatorname{VSMC}(47,49)$, thus implying that the downregulation of either receptor on VSMC would be associated with a decrease in VSMC response. It should be emphasized that in addition to the role in receptor downregulation, glucose-induced PKC activation may also exert direct downregulatory influences on postreceptor signal transduction mechanisms in VSMC (23, 50-52). Recently, the glucose-induced PKC activation has been characterized in cultured VSMC (53).

In conclusion, the present study uniquely demonstrates that high extracellular glucose concentrations depress the expression of AVP and AII receptors on VSMC. This effect is dependent on glucose-induced PKC activation and is likely to be of physiological significance in view of the associated marked attenuation of VSMC functional responses to AVP and AII. This novel mechanism may contribute to pressor receptor downregulation in early diabetes mellitus, thereby directly implicating hyperglycemia in the pathophysiology of hemodynamically mediated vascular injury in this disease.

\section{Acknowledgments}

The authors thank Carolyn Burke for the illustrations and Linda Benson for secretarial assistance.

This work was supported by a grant from the National Institutes of Health (DK 19928) and a grant from the Lucille P. Markey Charitable Trust.

\section{References}

1. Bensten, N., B. Larsen, and N. A. Lassen. 1975. Chronically impaired autoregulation of cerebral blood flow in long term diabetics. Stroke. 6:497-502.

2. Sinclair, S. H., J. E. Grunwald, C. E. Riva, et al. 1982. Retinal vascular autoregulation in diabetes mellitus. Ophthalmology. 89:748-750. 
3. Atherton, A., D. W. Hill, H. Keen, H. S. Young, and E. J. Edwards. 1980. The effect of acute hyperglycemia on the retinal circulation of the normal cat. Diabetilogica. 18:233-237.

4. Parving, H. H., J. Kastrup, U. M. Smidt, et al. 1984. Impaired autoregulation of glomerular filtration in type I diabetics with nephropathy. Diabetilogica. 27:547-552.

5. Mauer, M. S., D. M. Brown, M. W. Steffes, and S. Azar. 1990. Studies of renal autoregulation in pancreatectomized and streptozotocin diabetic rats. Kidney Int. 37:909-917.

6. Hashimoto, Y., T. Ideura, A. Yoshimura, and S. Koshikawa. 1989. Autoregulation of renal blood flow in streptozotocin-induced diabetic rats. Diabetes. 38:1109-1113.

7. Faris, I., H. V. Nielsen, O. Henricksen, H. H. Parving, and N. A. Larsen 1983. Impaired autoregulation of blood flow in skeletal muscle and subcutaneous tissue in long term type I diabetic patients with microangiopathy. Diabetilogica. 25:486-488.

8. Zatz, R., T. W. Meyer, H. G. Rennke, and B. M. Brenner. 1985. Predominance of hemodynamic rather than metabolic factors in the pathogenesis of diabetic glomerulopathy. Proc. Natl. Acad. Sci. USA. 82:5963-5967.

9. Zatz, R., and B. M. Brenner. 1986. Pathogenesis of diabetic microangiopathy: the hemodynamic view. Am. J. Med. 80:443-446.

10. Schrier, R. W., and H. Holzgreve. 1988. Hemodynamic factors in the pathogenesis of diabetic nephropathy. Klin. Wochenschr. 66:325-331.

11. Hostetter, T. H., J. L. Troy, and B. M. Brenner. 1981. Glomerular hemodynamics in experimental diabetes mellitus. Kidney Int. 19:410-415.

12. Schrier, R. W. 1988. Pathogenesis of sodium and water retention in highoutput and low-output cardiac failure, nephrotic syndrome, cirrhosis and pregnancy. N. Engl. J. Med. 319:1065-1072; 1127-1134.

13. Turlapaty, P. D. M. V., G. Lum, and B. M. Altura. 1980. Vascular responsiveness and serum biochemical parameters in alloxan diabetes mellitus. Am. J. Physiol. 239:E412-E421.

14. Reineck, H. J., and J. I. Kreisberg. 1983. Renal vascular responses to angiotensin II in rats with streptozotocin-induced diabetes mellitus. Kidney Int. 23:247. (Abstr.)

15. Ballerman, B. J., K. L. Skorecki, and B. M. Brenner. 1984. Reduced glomerular angiotensin II receptors in early untreated diabetes mellitus in the rat. Am. J. Physiol. 247:F110-F116.

16. Wilkes, B. M. 1987. Reduced glomerular angiotensin II receptor density in diabetes mellitus in the rat: time course and mechanism. Endocrinology. 120:1291-1298.

17. Thibonnier, M., and M. Woloschak. 1988. Platelet aggregation and vasopressin receptors in patients with diabetes mellitus. Proc. Soc. Exp. Biol. Med. 188:149-152.

18. Stiles, G. A., M. G. Caron, and R. J. Lef kowitz. 1984. $\beta$-adrenergic receptors: biochemical mechanisms of physiological regulation. Physiol. Rev. 64:661741.

19. Modesti, P. A., R. Abbate, G. F. Gensini, A. Colella, and G. G. N. Serneri. 1991. Platelet thromboxane $A_{2}$ receptors in type I diabetes. Clin. Sci. (Lond.). 80:101-105.

20. Nishizuka, Y. 1986. Studies and perspectives of protein kinase C. Science (Wash. DC). 233:305-312.

21. Nishizuka, Y. 1988. The molecular heterogeneity of protein kinase $\mathrm{C}$ and its implications for cellular regulation. Nature (Lond.). 334:661-665.

22. Kikkawa, U., A. Kishimoto, and Y. Nishizuka. 1989. The protein kinase C family: heterogeneity and its implications. Annu. Rev. Biochem. 58:31-44.

23. Caramelo, C., K. Okada, P. Tsai, and R. W. Schrier. 1989. Phorbol esters and arginine vasopressin in vascular smooth muscle cell activation. Am. J. Physiol. 25:F875-F881

24. Caramelo, C., P. Tsai, and R. W. Schrier. 1988. Mechanism of cellular effect of phorbol esters on action of arginine vasopressin and angiotensin II on rat vascular smooth muscle cells in culture. Biochem. J. 254:625-629.

25. Leeb-Lindberg, L. M. F., S. Cottechia, J. W. Lomasney, J. F. DeBernadis, R. J. Lef kowitz, and M. G. Caron. 1985. Phorbol esters promote alpha, adrenergic receptor phosphorylation and receptor uncoupling from inositol phosphate metabolism. Proc. Natl. Acad. Sci. USA. 82:5651-5655.

26. Jacobs, S., N. E. Sahyoun, A. R. Saltiel, and P. Cuatecasas. 1983. Phorbol esters stimulate the phosphorylation of receptors for insulin and somatomedin C. Proc. Natl. Acad. Sci. USA. 80:6211-6213.

27. Takayama, S., M. F. White, and C. R. Kahn. 1984. Phorbol esters modulate insulin receptor phosphorylation and insulin action in cultured hepatoma cells. Proc. Natl. Acad. Sci. USA. 81:7797-7801.

28. Eldar, H., Y. Zisman, A. Ullrich, and E. Livneh. 1990. Overexpression of protein kinase $\mathrm{C}_{\mathrm{a}}$-subtype in Swiss/3T3 fibroblasts causes loss of both high and low affinity receptor numbers for epidermal growth factor. J. Biol. Chem. 265:13290-13296.
29. Craven, P. A., C. M. Davidson, and F. R. DeRubertis. 1990. Increases in diacylglycerol mass in isolated glomeruli by glucose from de novo synthesis of glycerolipids. Diabetes. 39:667-674.

30. Hise, M. K., and P. S. Mehta. 1988. Characterization and localization of calcium/phospholipid dependent protein kinase $\mathrm{C}$ during diabetic renal growth Endocrinology. 123:1553-1558.

31. Lee, T. S., L. C. MacGregor, S. J. Fluharty, and G. L. King. 1989. Differential regulation of protein kinase $\mathrm{C}$ and $\mathrm{Na}^{+} / \mathrm{K}^{+}$-ATPase activities by elevated glucose levels in retinal capillary endothelial cells. J. Clin. Invest. 83:90-94.

32. Craven, P. A., and F. DeRubertis. 1989. Protein kinase $C$ is activated in glomeruli from streptozotocin diabetic rats. Possible mediation by glucose. $J$. Clin. Invest. 83:1667-1675.

33. Meyer-Lehnert, H., C. Caramelo, P. Tsai, and R. W. Schrier. 1989. Interaction of atriopeptin III and vasopressin on calcium kinetics and contraction of aortic smooth muscle cells. J. Clin. Invest. 82:1407-1414.

34. Caramelo, C., K. Okada, P. Tsai, S. Linas, and R. W. Schrier. 1990. Interaction of arginine vasopressin and angiotensin II on $\mathrm{Ca}^{2+}$ in vascular smooth muscle cells. Kidney Int. 38:47-54.

35. Heasley, L. E., and G. L. Johnson. 1989. Regulation of protein kinase C by nerve growth factor, epidermal growth factor and phorbol esters in PC12 pheochromocytoma cells. J. Biol. Chem. 264:8646-8652.

36. Heasley, L. E., and G. L. Johnson. 1989. Detection of nerve growth factor and epidermal growth factor regulated protein kinases in PC12 cells with synthetic peptide substrates. Mol. Pharmacol. 35:331-338.

37. Davis, R. J., and M. P. Czech. 1985. Tumor promoting phorbol esters cause phosphorylation of epidermal growth factor receptors in fibroblasts at threonine-654. Proc. Natl. Acad. Sci. USA. 82:1974-1978.

38. Bell, R. M. 1986. Protein kinase C activation by diacylglycerol second messengers. Cell. 45:631-632.

39. Kraft, A. S., and W. B. Anderson. 1983. Phorbol esters increase the amount of calcium phospholipid dependent protein kinase associated with the plasma membrane. Nature (Lond.). 301:621-623.

40. Caramelo, C., P. Tsai, K. Okada, V. A. Briner, and R. W. Schrier. 1991. Mechanisms of rapid desensitization to arginine vasopressin in vascular smooth muscle cells. Am. J. Physiol. 29:F46-F52.

41. Okada, K., P. Tsai, V. A. Briner, C. Caramelo, and R. W. Schrier. 1991 Effects of extra- and intracellular $\mathrm{pH}$ on vascular action of arginine vasopressin. Am. J. Physiol. 29:F39-F45.

42. Chamley-Campbell, J. H., G. R. Campbell, and R. Ross. 1979. The smooth muscle cell in culture. Physiol. Rev. 59:1-61.

43. Hidaka, H. F., M. Inagaki, S. Kawamoto, and Y. Sasaki. 1984. Isoquinoline sulfonamides, novel potent inhibitors of cyclic nucleotide dependent protein kinases and protein kinase C. Biochem. J. 23:5036-5041.

44. Caramelo, C., K. Okada, P. Tsai, and R. W. Schrier. 1988. Mechanisms of the vascular effect of pressor hormones. Am. J. Cardiol. 62:47G-53G.

45. Adelstein, R. S., and D. R. Hathaway. 1979. Role of calcium and cyclic adenosine $3^{\prime}, 5^{\prime}$-monophosphate in regulating vascular smooth muscle cell contraction: mechanisms of excitation-contraction coupling in smooth muscle. $\mathrm{Am}$. J. Cardiol. 44:783-787.

46. Okumura, K., N. Akiyama, H. Hashimoto, K. Ogawa, and T. Satake. 1988. Alteration in 1,2-diacylglycerol content in myocardium from diabetic rats. Diabetes. 37:1168-1172.

47. Tsai, P., K. Okada, C. Caramelo, and R. W. Schrier. 1989. Characterization of arginine vasopressin $V_{1}$ receptor in rat vascular smooth muscle cells in culture. Clin. Res. 37:503a. (Abstr.)

48. Ullian, M. E., and S. L. Linas. 1989. Role of receptor cycling in the regulation of angiotensin II surface receptor number and angiotensin II uptake in rat vascular smooth muscle cells. J. Clin. Invest. 84:840-846.

49. Ullian, M. E., and S. L. Linas. 1990. Angiotensin II surface receptor coupling to inositol trisphosphate formation in vascular smooth muscle cells. $J$. Biol. Chem. 265:195-200.

50. Gonzalaes, R. A., P. H. Greger, S. P. Baker, et al. 1987. Phorbol esters inhibit agonist stimulated phosphoinositide hydrolysis in neuronal primary cultures. Dev. Brain Res. 37:59-66.

51. Pfeilschifter, J. M. 1986. Tumor promoter 12-o-tetradecanoylphorbol 13-acetate inhibits angiotensin II-induced inositol phosphate production and cytosolic $\mathrm{Ca}^{2+}$ rise in rat mesangial cells. FEBS (Fed. Eur. Biochem. Soc.) Lett. 203:262-266.

52. Pfeilschifter, J. M. 1988. Protein kinase C from rat renal mesangial cells: its role in homologous desensitization of angiotensin II-induced polyphosphoinositide hydrolysis. Biochim. Biophys. Acta. 969:263-270.

53. Williams B., and R. W. Schrier. Characterization of glucose-induced protein kinase $\mathrm{C}$ activation in cultured vascular smooth muscle cells. Diabetes. In press. 